\title{
Implementation of Google Maps API and Firebase for Android Based Photographer Marketplace Information System
}

\author{
I Ketut Wahyu Ariprasasmita \\ Department of Information \\ Technology \\ Faculty of Engineering \\ Udayana University \\ Badung, Bali, Indonesia
}

\author{
I Nyoman Piarsa \\ Department of Information \\ Technology \\ Faculty of Engineering \\ Udayana University \\ Badung, Bali, Indonesia
}

\author{
Kadek Suar Wibawa \\ Department of Information \\ Technology \\ Faculty of Engineering \\ Udayana University \\ Badung, Bali, Indonesia
}

\begin{abstract}
Nowadays, people increasingly need photography services for personal documentation. They often use social media to share their photography content. Photographers also use social media as a promotional media, however, that does not make it easier for people to get in contact with them. It is because social media such as Instagram or Facebook are not a special platform for providing photography services, in addition, they cannot make photography service transactions easily. An Android-based photographer marketplace information system is the solution to these problems. By using the Google Maps API and Firebase, this system is an application system on the Android platform that is developed to connect photographers and consumers in order to make an easy transaction. This system uses the Google Maps API for mapping the location of photographers, MySQL as user data storage, and the Firebase API for creating messages and notification features in real-time.
\end{abstract}

Keywords: Photographer; Marketplace; Android; Google Maps API; Firebase; Information System

\section{INTRODUCTION}

A data from the Ministry of Tourism Indonesia in 2013 showed that the photography subsector contributed a gross value added (GVA) of $1 \%$ to the GVA total of the creative industry in Indonesia, with an average growth of $6.94 \%$ in 2010-2013 [1]. This economic growth also had an impact on the emergence of new photographers because it is considered as a profession with a promising income. However, there are some problems in connecting between photographers and consumers. This problem appears when a consumer travels to a new place and want to find a photographer. The use of local photographer services is a solution to these problems for improving the economy of the local area and it also can ease people's expenses when traveling to an area.

This study tries to develop a system that can be a place where photographers are more easily found. By creating a mobilebased marketplace system, it will be easier for the people to interact and transact with them. In addition, they can take photo sessions more easily wherever they are. Therefore, a mobile-based marketplace can be a suitable place for local photographers in an area.

The developed system consists of 3 systems, namely for consumers, photographers, and also for administrators. This system has supporting features such as an ability in uploading a photography gallery as a photographer's portfolio, giving ratings and reviews to photographers, booking photography services and making payments. The consumers and photographers can also communicate with chat features and get notifications by using Firebase. Another service that can be used is the photographer can determine their available date, therefore the consumers can find them on a specific date. The consumers can also find photography service as they want based on price or the nearest location which uses the Google Maps API. Administrators validate the photographers, as the result, the registered photographer is the one who has been selected by the administrator.

\section{LITERATURE REVIEWS}

A study related to e-commerce and the benefits of ecommerce in the field of creative industries previously conducted by Aleck C.H [2]. The journal entitled Facilitating Cultural and Creative Industries to Engage the Internet Era: A New E-Commerce Strategic Framework describes the phenomenon of new global economic growth, when Cultural and Creative Industries (CCI) are involved in the Internet era. This study is used as a reference to the importance of implementing digital platforms especially in e-commerce for Cultural and Creative Industries (CCI).

A study on the application of photography services was previously done by Mahdy Arief in 2015. The result of this study is developing a Web-Based E-Commerce Application for Pre-Wedding Photography Services Crowdsourcing Photographer Modules by Using Iterative Incremental Methods [3]. This study is used as a reference in developing e-commerce information systems in the photography business.

A study related to e-commerce information systems by using the Google Maps API as a provider of Geographic Information Systems was previously conducted by Santosa in 2017. The result of this study is Pyle: Web-Based ECommerce Applications by Using Geographic Information Systems [4]. This study contributes as a reference in developing e-commerce systems and Google Maps API.

A study entitled Customer to Customer (C2C) Vehicle Rental Information System by Sugi is a study related to the implementation of the Android-based e-commerce method. This study designed a vehicle rental application called SIRENT. This application aims to improve the quality of business for vehicle owners in marketing their vehicles by using the Customer to Customer method [5]. The use of this 
study is as a reference in developing e-commerce systems and geographic information systems.

FinDoctor-Interactive Android Clinic's Geographical Information System Using Firebase and Google Maps API conducted by Anisa Rahmi in 2017 is a study related to geographic information systems by using the Android-based Google Maps API. The study proposes mobile and web applications to facilitate the needs of doctors and patient. The results of this study indicate that Firebase has successfully provided a real-time database, push notification, and storage. The Google Maps API has also succeeded in supporting accurate maps and locations [6]. This study contributes as a reference to the use of the Google Maps API and Firebase in the features of the developed application.

\section{RESEARCH METHOD}

\subsection{Research Flow}

The research flow of Android-based photography business to consumer marketplace information system can be seen in Figure 1 .

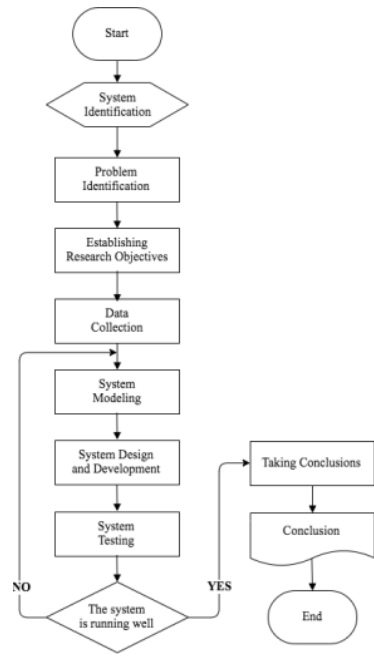

Figure 1. Research Flowchart

Figure 1 is a research flowchart used in designing Androidbased photographer marketplace information systems. The process that occurs includes defining the developed system, identifying problems that occur related to the developed system, setting research goals, collecting data and literature study that related in developing the system, modeling the system by collecting and understanding things that can be occur in the system, designing and developing the system by designing database as a location for storing data, making program code for the system, and testing the system and documentation of test results. If the system runs well and correctly, conclusions will be drawn. If it is not, it will return to the system modeling stage.

\subsection{General Overview}

A general overview of the Android-based photographer marketplace information system can be seen in Figure 2 below.

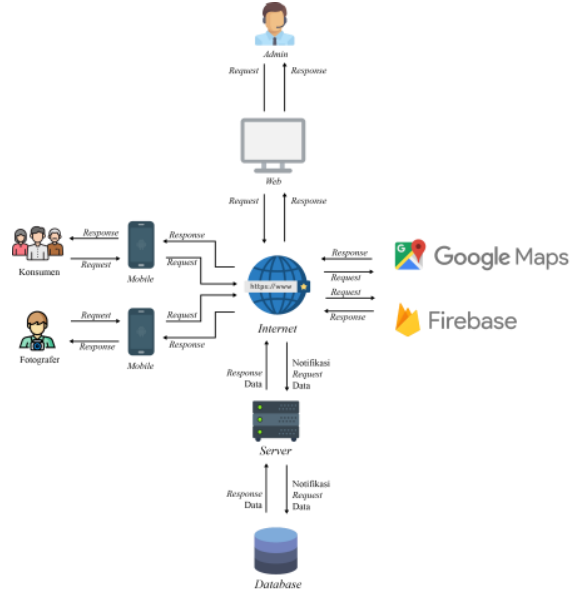

Figure 2. General Overview

Figure 2 is a general overview of the photographer's marketplace information system which is an explanation of the management processes that are implemented in the system. Request data sent by the admin are done by using a server computer that is connected to the internet. Meanwhile, request data sent by photographers and consumers are done by using an Android mobile that is connected to the internet. All results of request data made by admin, photographers and consumers will be stored on a database server that is connected to the internet, and it is distributed back in the form of responses by using third-party services such as Google Maps and Firebase.

\subsection{Context Diagram}

A general overview of the Android-based photographer marketplace information system can be seen in Figure 3 below.

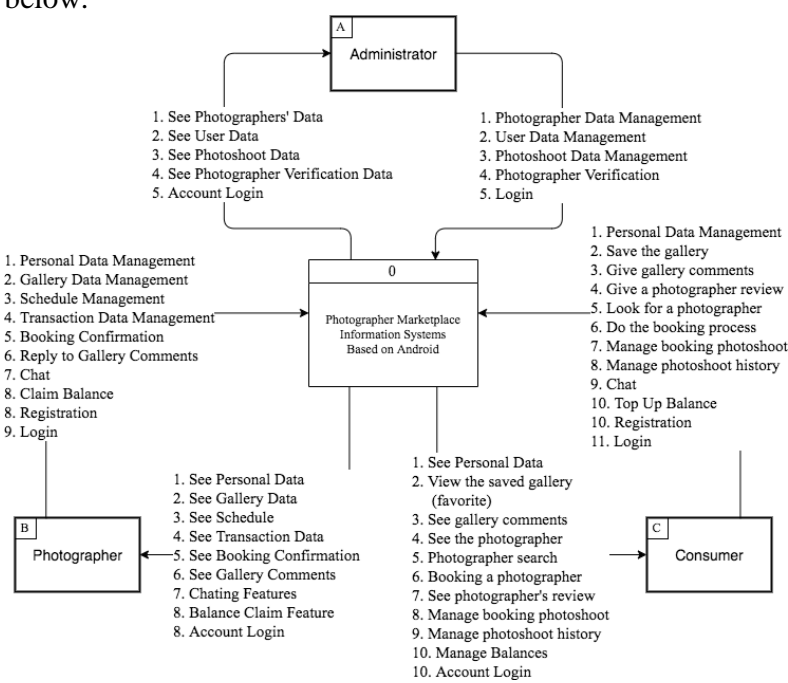

Figure 3. Context Diagram

The context diagram shown in Figure 3 presents that the developed system consists of 3 main entities, namely the admin entity, the photographer entity, and the consumer entity. The admin receives photographer verification requests that are entered by the photographer. Then, they provide feedback to the system by verifying the photographer's data. In addition, they also accepts consumer data and photo shoot data. Data which flows from the admin entity to the system are photographer's data, consumer data, photo shoot data, and also photographer verification data. 
Data inputted by photographers into the system are personal data, gallery data, schedules, transaction data, booking confirmations, photographer and consumer chat, and balance claims. Data which flows from the system is the photographer's personal data, photographer's gallery data, schedule status, transaction data, booking confirmation status, photographer and consumer chat, and photographer's balance.

Data inputted by costumer to the system is their personal data includes edited ones, favorite gallery data, gallery review data, photographer review data, photographer search data, photographer booking data, photographer chat, and top-up balance. Data which flows from the system are personal data of consumers, favorite photographer's gallery data, gallery review data, photographer review data, booking status, and customer balances.

\subsection{Database Design}

Database design of the Android-based photographer marketplace information system can be seen in Figure 4 below.

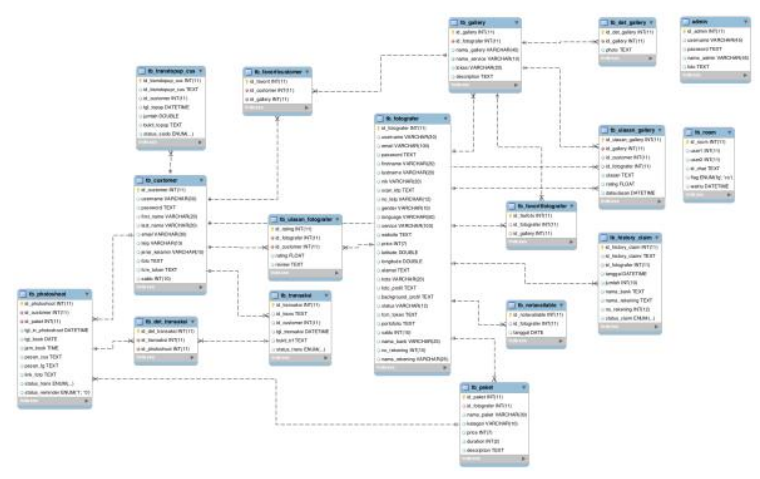

Figure 4. Database Design

Figure 4 is a MySQL database application design that displays relations between tables used in Android-based marketplace geographic information systems. This geographic system has 17 interconnected tables. Here, MySQL database stores data such as photographer's data, consumer data, gallery data, transaction data and available date schedule of photographers. Data files of the photographer's portfolio that wanted to be verified and chat data are stored in Firebase using Firebase Storage. It is used for the purpose of sharing storage loads.

\subsection{Application Features}

The application features of the Android-based photographer marketplace information system can be seen in Table 1 below.

Table 1. Application Features

\begin{tabular}{|c|c|c|}
\hline Administrator & Photographer & Consumer \\
\hline Web Based & $\begin{array}{c}\text { Personal data } \\
\text { management }\end{array}$ & $\begin{array}{c}\text { Personal data } \\
\text { management }\end{array}$ \\
\hline $\begin{array}{c}\text { Photographer } \\
\text { data } \\
\text { management }\end{array}$ & $\begin{array}{c}\text { Create Photo } \\
\text { Gallery }\end{array}$ & Find photographers \\
$\begin{array}{c}\text { Customer data } \\
\text { management }\end{array}$ & $\begin{array}{c}\text { Schedule } \\
\text { management }\end{array}$ & $\begin{array}{c}\text { Find and leave } \\
\text { comment on } \\
\text { photographers } \\
\text { galleries }\end{array}$ \\
\hline $\begin{array}{c}\text { Administrator } \\
\text { data } \\
\text { management }\end{array}$ & $\begin{array}{c}\text { Manage booking } \\
\text { request }\end{array}$ & $\begin{array}{c}\text { Booking } \\
\text { photographer }\end{array}$ \\
\hline $\begin{array}{c}\text { Transaction } \\
\text { data }\end{array}$ & $\begin{array}{c}\text { Transaction } \\
\text { management }\end{array}$ & $\begin{array}{c}\text { Review } \\
\text { photographer }\end{array}$ \\
\hline
\end{tabular}

\begin{tabular}{|c|c|c|}
\hline management & & \\
\hline \multirow[t]{7}{*}{$\begin{array}{l}\text { Photographer } \\
\text { verification }\end{array}$} & $\begin{array}{l}\text { Find other } \\
\text { photographer } \\
\text { galleries }\end{array}$ & $\begin{array}{c}\text { Phone, instant } \\
\text { messaging, chating }\end{array}$ \\
\hline & $\begin{array}{l}\text { Find other } \\
\text { photographer }\end{array}$ & $\begin{array}{l}\text { Direction to } \\
\text { photographer } \\
\text { location }\end{array}$ \\
\hline & $\begin{array}{l}\text { Add favorite } \\
\text { gallery }\end{array}$ & Top up balance \\
\hline & $\begin{array}{c}\text { Comment on own } \\
\text { gallery }\end{array}$ & Register account \\
\hline & Claim balance & Login account \\
\hline & Register account & \\
\hline & Login account & \\
\hline
\end{tabular}

Table 1 is a feature list that can be used by users. The users of this application are divided into 3 namely consumers, photographers, and admin. It appears that the admin has more important access because they can manage accounts from the user's application and delete or verify users who can use the application. Furthermore, admin can manage data transactions that occur between photographers and consumers. The features owned by photographers and consumers are almost the same. However, for photographers, they can upload a portfolio gallery through the application and can be given a response by the consumers. Photographers and consumers can communicate through the provided chat feature. The consumers can find the photographers with several options such as the nearest photographer, a certain schedule, the lowest price, and the type of service that photographers provide. In addition, they can make payments through this application by topping up the balance first.

\section{CONCEPT AND TEORIST}

\subsection{Information System}

The information system is a sequence of formal procedures where data are grouped, processed into information, and distributed to users [7]. According to Krismaji, information systems are organized methods to collect, enter, process and store data. In addition, it also store, manage, control, and report information in such a way, therefore an organization can achieve its stated goals

\subsection{Geographic Information System}

Piarsa defines Mobile GIS as a mobile device capable of displaying geospatial data, receiving, processing, and receiving telephone user requests [8]. Mobile GIS can be divided into two types according to how to access data and collect information, namely Fieldbased GIS and Location Based Services.

\subsection{E-commerce}

E-commerce can be classified into several models, namely Business to Business (B2B), Business to Consumer, Business to Government (B2G), Consumer to Business (C2B), Consumer to Consumer (C2C), Consumer to Government (C2G), Government to Business (G2B), Government to Consumer (G2C) and Government to Government (G2G) [9]. The Ministry of Finance Indonesia classifies e-commerce transaction business models into four models, such as Online Marketplace, Classified Ads, Daily Deals, and Online Retail [10]. 


\subsection{API}

API or Application Programming Interface is not just a simple set of classes and methods or functions and signatures. API has a main goal to overcome the "clueless" in developing large-sized software, starting from something simple to complex and is a component behavior that is difficult to understand. In general, API or Application Programming Interface can be defined as a link between software to other software.

\subsection{Google Maps API}

Google Maps offers an API for building web-based applications or mobile-based applications. Android as a mobile-based application allows developers to integrate Google Maps with applications and provide functions such as displaying locations in the form of maps, showing different routes on the map, etc. The Google map API can be used to create distribution mapping data. The advantage of it in Android is that it can support real-time coordinate processes using GPS technology [6].

\subsection{Firebase}

Firebase is a platform that can help developers in developing high-quality applications. Firebase stores data in the JavaScript Object Notation (JSON) format that does not use queries to insert, update, delete, or add data to it. JSON is the backend of the system that is used as a database to store data [11].

\subsection{Android}

Android provides an open platform for developers to create their own applications to be used by a variety of mobile devices. Android is commonly used on smartphones and tablet PCs. It functions the same as the Symbian operating system on Nokia, iOS on Apple and BlackBerry OS [12].

\section{IMPLEMENTATION RESULTS}

The features contained in the Android based photographer marketplace geographical information system have different functions and objectives. The features of application system by using a mobile device on client side are as follows.

\subsection{Photographer}

Important features that can be used by consumer in this Android-based photographer marketplace information system are as follows.

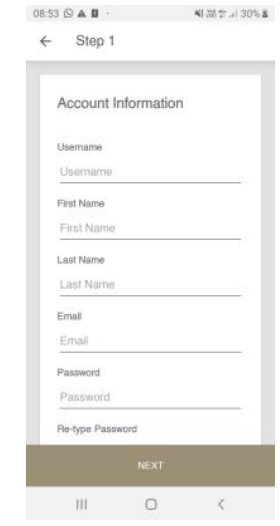

(a)

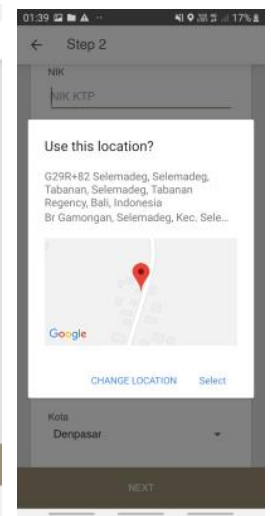

(b)

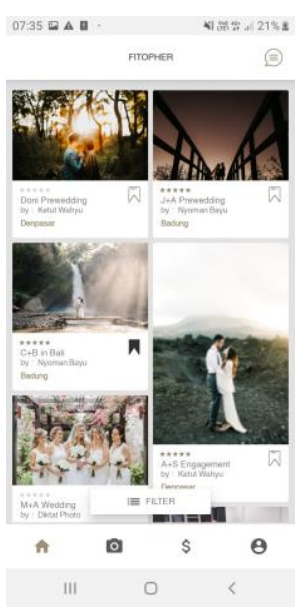

(c)

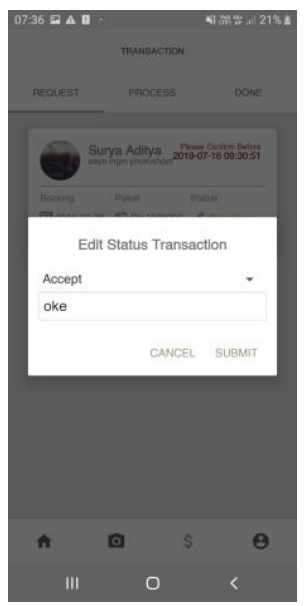

(e)

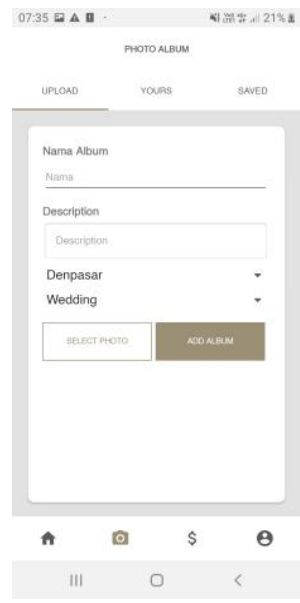

(d)

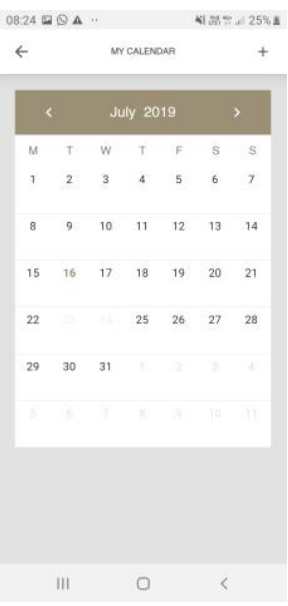

(f)
Figure 5. Result on Photographer Application

Figure 5(a) is a screen shot of photographer registration. First, the photographers must register by filling out the registration form which contains the username, email, and password. They must attach their portfolio in the form of a PDF file for a selection process to join in the application. If their status has not been approved by the admin, they cannot use the overall application features such as uploading galleries or accepting bookings from consumers. Furthermore, they can add their locations with the 'place picker' feature that used the Google Maps API, therefore consumers can be easier to find their location as shown in Figure 5(b). Figure 5(c) is the home page that the photographer can access when their account has been verified by the admin. The home page contains photographers' galleries which can be seen and commented by consumers or them. If the admin has verified them, they can upload the gallery, therefore it can be appeared on the home page. They must include more than 1 photo and provide captions to the gallery as shown in Figure 5(d). Figure 5(e) is the photographer's booking approval page. They can choose the status of approval by choosing pending, approve or decline and provide information on the incoming booking list. The consumers can make the booking process with them. The booking data must be approved by the photographer before the transaction can proceed to the payment process. If within 2 hours it is not responded by them or the booking status is still pending, it will be automatically deleted by the system. Another feature for the photographer is that they can determine the date when they cannot accept orders 
by setting "not available" date on the application. In addition, they can determine the date when they are not available as seen in Figure 5(f). It is determined by them and it will be in the color of gray. As the result, the customer cannot choose it when making a booking.

\subsection{Consumer}

Important features that can be used by photographers in this Android-based photographer marketplace information system are as follows.

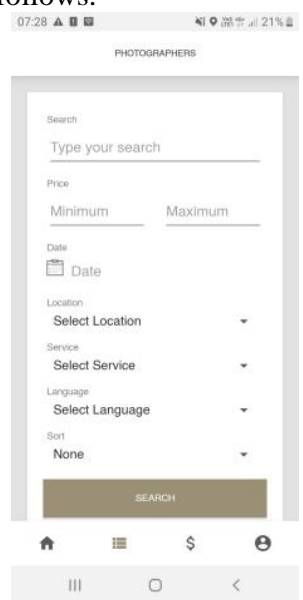

(a)

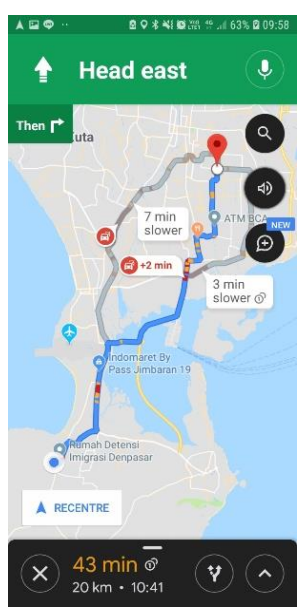

(c)

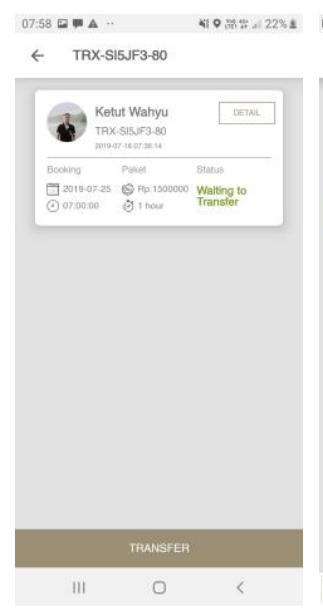

(e)

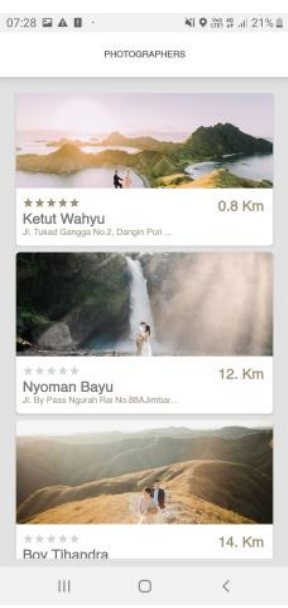

(b)

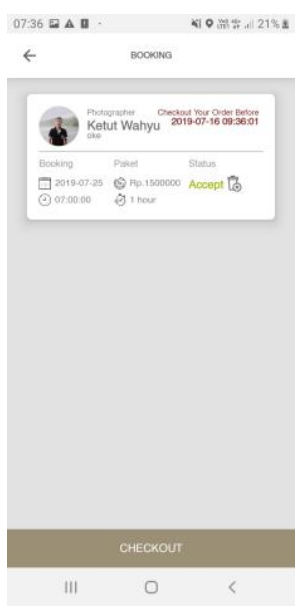

(d)

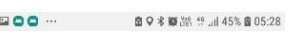

Ketut Wahyu

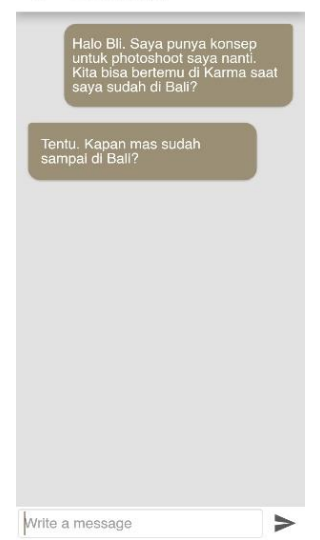

(f)

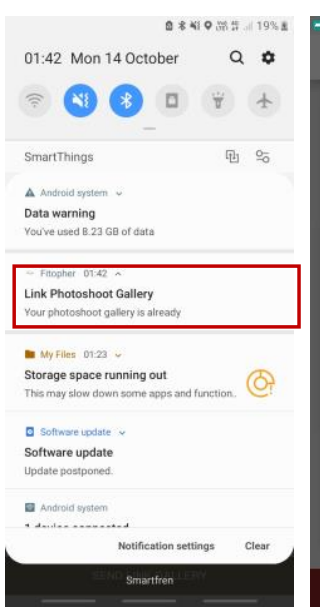

(g)

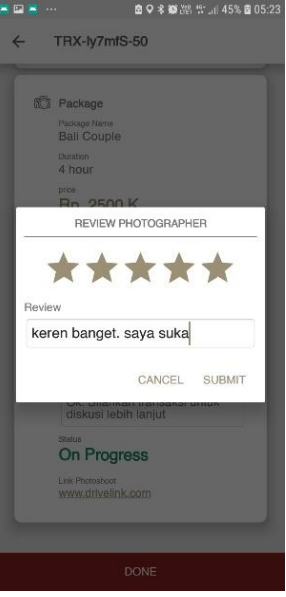

(h)
Figure 6. Result on Consumers Application

The consumers can find photographers in the application by selecting the searching menu as shown in Figure 6(a). They can fill in input data, such as username, photographer package price, type of service provided by the photographer, the language understood by the photographer, sorting by rating or prices and searching for the nearest photographers. Figure $6(b)$ is a screen shot of the photographer search menu based on the nearest location of the customer. Furthermore, the consumers can be directed to where the photographer is located by selecting the direction button on the selected photographer's profile, then it will then be redirected to the google maps direction page as shown in Figure 6(c). Photography services can be ordered by booking the photographer first. Figure 6(d) is a display of the process of photographer booking that can be done by consumers who have logged in. In ordering photographer services, the customer can choose the booking button found on the photographer's detail page and then choose one of the photographer's packages. After that, they are required to fill in a booking form consisting of the date of booking, booking hours, and messages to be conveyed to the photographer after they choose one of the desired photography service packages. The booking data contain photographer's package names and descriptions, costs, photo shoot duration, booking dates, booking hours, and messages from consumers will be sent to the photographer after they selects the send button. If the booking list has not been checked by the consumer for more than 2 hours, then it has not been sent to the photographer and it will be automatically deleted by the system. Figure 6(e) is a display of payment transactions. Booking that has been approved must be processed immediately because if it stays for more than 30 minutes, it will be deleted automatically by the system. Consumers are required to transfer payments to the account of application provider before it is forwarded to the photographer after the photo shoot process is complete. The consumers can have a conversation with the photographer by using chat features. It is developed by using a database, therefore messages can be received in real-time. Figure 6(f) is a display of chat features that can be used by consumers and photographers. Also, they will receive realtime notifications from the system such as receiving transaction status as shown in Figure $6(\mathrm{~g})$. Another feature that can be implemented is giving ratings in the form of stars and comments that can be entered in the edit text for the photographer after the transaction has ended as shown in Figure $6(\mathrm{~h})$. This rating data will go directly to the 
photographer page as a review for potential consumers to consider using the services of the chosen photographers.

\subsection{Administrator}

Important features that can be used by administrator in this Android-based photographer marketplace information system are as follows.

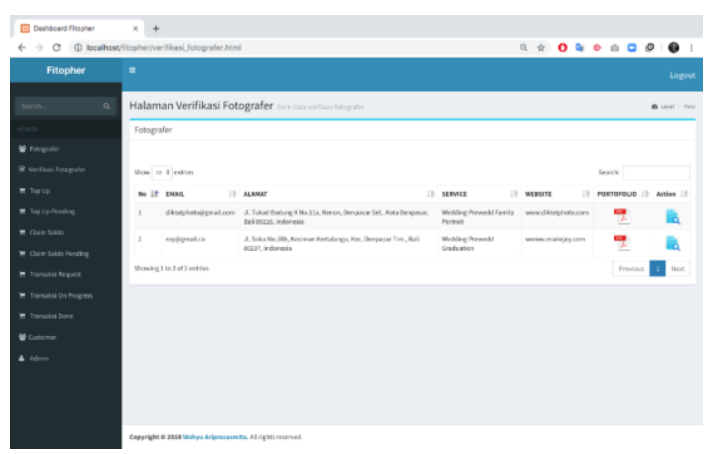

(a)

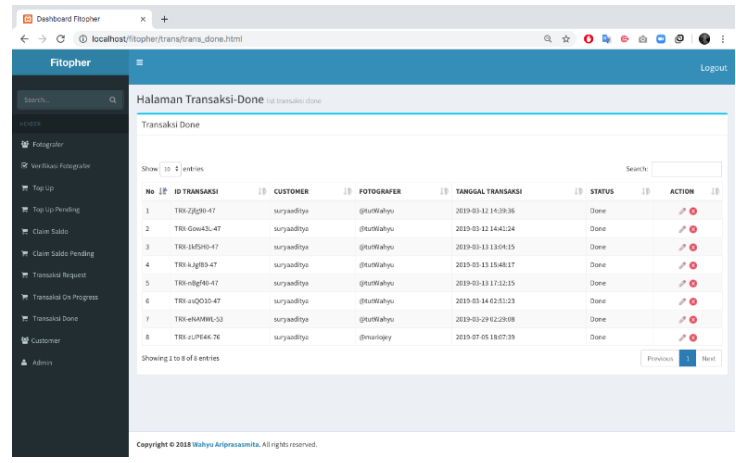

(b)

Figure 7. Result on Administrator web

Administrator can do a process of selecting photographers who register to the system. Data of photographers who have registered can be seen in Figure 7(a). The administrator has the right to choose a photographer by considering their personal data and attached portfolio. In addition, the administrator has the right to manage data on transactions and users by using web-based applications like in Figure 7(b).

\section{RESULTS}

The conclusion that can be drawn from this study is the photographer marketplace information system is developed by using the Android platform on the client side. Meanwhile, on the server side, website can be used to bring consumers together with local photographers and also as a promotional media for them through their gallery portfolio. This application proposes three panels, including Admin, Photographer, and Consumer. The developed application also contains detailed information from the photographer such as their locations by using the Google Maps API and making it easier for the consumers to meet them. In addition, it successfully applies Firebase real-time database, Firebase push notification, and Firebase storage to create features in applications such as chat and save the portfolio file data of photographers who register to the application. Features that are created by using the Google Maps API and Firebase can help to solve problems in finding photographers and making transactions with them more easily.

\section{REFERENCES}

[1] A. Utami and M. Kitri, Ekonomi Kreatif: Rencana Pengembangan Penelitian \& Pengembangan Nasional 2015-2019, August 2017. 2015.

[2] A. C. H. Lin, "Facilitating Cultural and Creative Industries to Engage the Internet Era: A New ECommerce Strategic Framework," Am. J. Econ., vol. 5, no. 5, pp. 534-539, 2015

[3] M. Arief and T. N. Adi, "Membangun Aplikasi ECommerce Jasa Fotografi Pre Wedding Berbasis Web Crowdsourcing Modul Fotografer Menggunakan Metode Iterative Incremental," vol. 2, no. 2, pp. 5782 $5790,2015$.

[4] P. A. D. Santosa, "PYLE: Aplikasi E-Commerce Berbasis Web Menggunakan Sistem Informasi Geografis" Kumpul. Artik. Mhs. Pendidik. Tek. Inform., vol. Vol.6, p. No.1, 2017.

[5] I. P. S. Almantara, "Sistem Informasi Penyewaan Kendaraan Bermotor Customer to Customer ( C2C )," $J$. Ilm. Merpati Univ. Udayana, vol. 5, no. 3, pp. 219-227, 2017.

[6] A. Rahmi, "FinDoctor - Interactive Android Clinic Geographical Information System Using Firebase and Google Maps API," Int. J. New Technol. Res., vol. 3 , no. 7, pp. 8-12, 2017.

[7] A. Kadir, Pengenalan Sistem Informasi Edisi Revisi. Yogyakarta: Andi Yogyakarta, 2014.

[8] I. N. Piarsa, "Rural Road Mapping Geographic Information System Using Mobile Android," vol. 12, no. 3, pp. 95-100, 2015.

[9] W. Febriantoro, "Kajian Dan Strategi Pendukung Perkembangan E- Commerce Bagi Umkm di Indonesia" vol. 3, no. 5, pp. 184-207, 2016.

[10] Kementerian Keuangan Republik Indonesia, Surat Edaran Direktur Jenderal Pajak No. SE-62/PJ/2013 tentang Penegasan Ketentuan Perpajakan atas Transaksi E-commerce. Jakarta: Kementerian Keuangan RI, 2013.

[11] C. Khawas and P. Shah, "Application of Firebase in Android App Development-A Study," Int. J. Comput. Appl., vol. 179, no. 46, pp. 49-53, 2018.

[12] N. Safaat H, Pemograman Aplikasi Mobile Smartphone dan Tablet PC Berbasis Android. Bandung: Informatika, 2012 